\title{
RETICULATE EVOLUTION IN THE APPALACHIAN ASPLENIUMS ${ }^{1}$
}

\author{
WARREN H. WAGNER, JR. \\ Department of Botany, University of Michigan, Ann Arbor, Michigan
}

Received, October 20, 1953

\section{NTRODLCTION}

To be able to postulate the course of evolution in a group of organisms on the basis of indirect evidence is one of the goals of phylogenetic research, since in many groups direct evidence is difficult or impossible to obtain. Occasionally a worker may be fortunate enough to confirm his indirect and comparative techniques by direct evidence, such as the discovery of a postulated ancestral type, or the production of a postulated form by hybridization experiments. In the present study of the evolution of the Appalachian Aspleniums, a complex group of small ferns of the eastern United States, the methods used have been indirect ones, morphological, anatomical, and cytological. But in future years it is to be expected that experimental proof of the conclusions of this study will be forthcoming. The indirect steps used as evidence of reticulate evolution in the Appalachian Aspleniums are thus subject to validation by direct tests.

Wherry $(1925,1936)$ pointed out that the Appalachian Aspleniums "form a series showing intermediates between certain long-recognized species." His basic end-point species were five in number: Asplenium pinnatifidum (lobed spleenwort), $A$. montanum (mountain spleenwort), $A$. bradleyi (cliff spleenwort), $A$. platyneuron (ebony or brownstem spleenwort), and $A$. rhizophyllum (the walking-fern, usually treated as Camptosorus rhizophyllus but for sake of simplicity retained in Asplenium here ). Detailed studies of the morphology of these five end-

1 This study was aided by a Faculty Research Grant from the Horace H. Rackham School of Graduate Studies.

Evolution 8: 103-118. June, 1954. point species and comparisons of them with their various intermediates suggest that within the complex totalling $11 \mathrm{de}$ scribed entities, the real extremes are only three in number. These three species are $A$. montanum, $A$. platyneuron, and $A$. rhizophyllum. All the remaining taxa. commonly treated as species or hybridsincluding the familiar $A$. pinnatifidum and $A$. bradleyi-lie somewhere between these three extremes in their morphology.

Among students of the Filicineae it has been rather conventional to consider as hybrids only those intermediate forms which occur as single, sterile plants with obvious parents growing nearby. But with the increasing recognition of allopolyploidy as a factor in species formation in plants, sterility per se is no longer the sole signpost of hybrid origin. Indeed, the best-known fern hybrid, Asplenium ebenoides ( $A$. platyneuron $\times A$ rhizophyl$l u m)$, though usually sterile, occurs as a fertile form in one large population in Alabama. It has not, however, been examined cytologically until the present study (Wagner, 1953), nor have any others of the Appalachian Aspleniums been so investigated. The aim of the present work has been not only to clarify the cytological picture of the group, but also to use any other available indirect approaches to its evolutionary history. Thus certain morphological and anatomical features were found valuable in interpreting the intermediate forms. The evidence now indicates that a complex of eight described entities, $A$. ebenoides, $A$. pinnatifidum, A. trudellii, A. kentuckiense, $A$. gravesii, $A$. bradleyi, $A$. bradleyi $\times A$. platyneuron, and $A$. bradleyi $\times A$. montanum, has arisen as a result of hybridiza- 
tion between three ancient and original species.

The three basic species are entirely distinctive, whereas the remaining taxa constitute a difficult group, as shown by diverse herbarium identifications and taxonomic interpretations. Asplenium montanum (fig. 1, M) shows notably the following peculiarities: (1) triangular, long-petiolate, 2-3-times dissected leaf blades, (2) dark-brown color of the leaf axis present only at the base of the flattened petiole, (3) "glossy" upper leaf surface, resulting from the markedly elongate, practically straight-walled form of the epidermal cells, and (4) occurrence strictly in acid-rock crevices. The closest relative of $A$. montanum appears to be the wide-ranging $A$. adiantum-nigrum of the western United States, Africa, Eurasia,

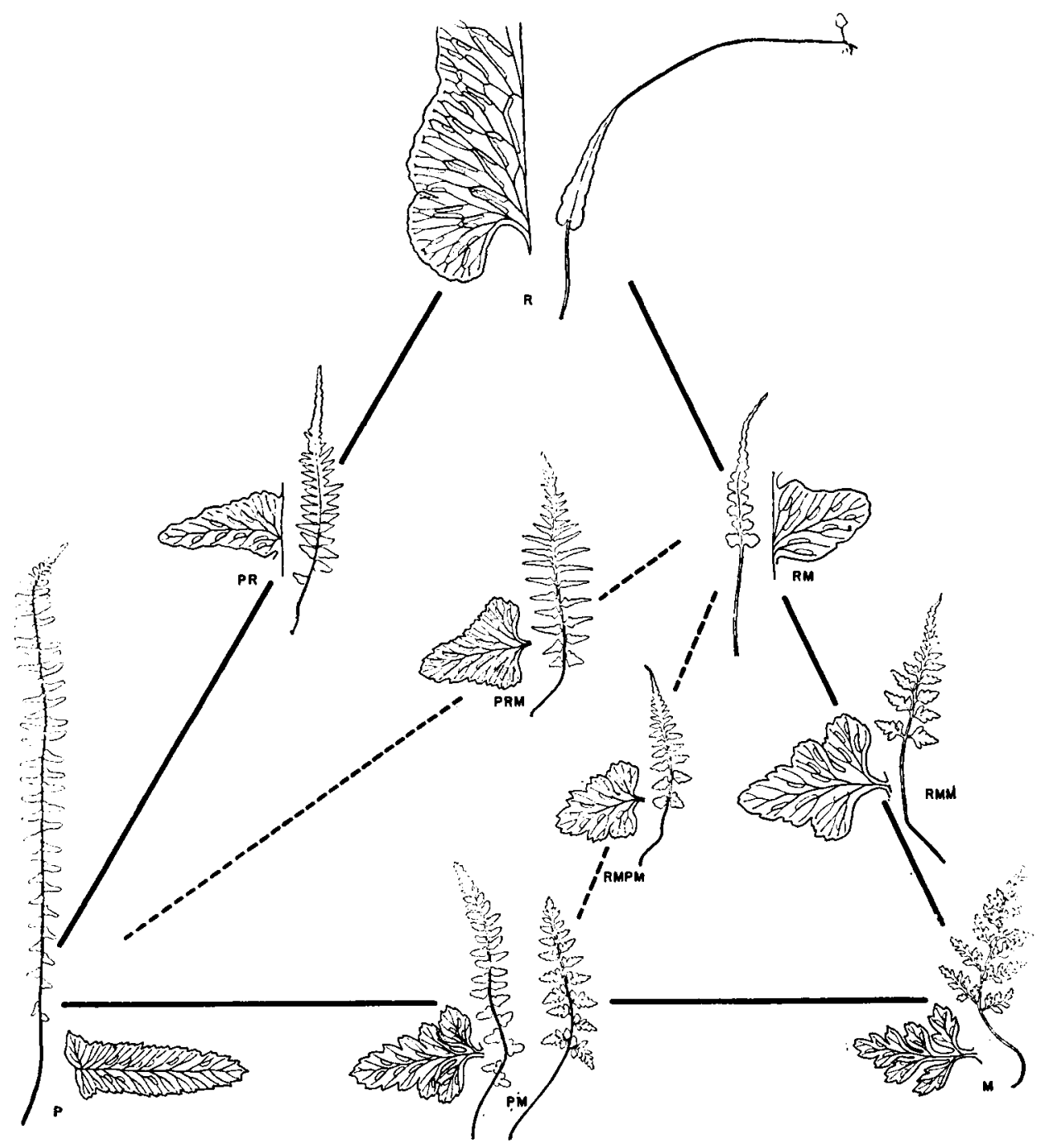

FIG. 1. Concept of relationships in the Appalachian Aspleniums. R. Asplenium rhizophyllum: P. A. platyneuron; M. A. montanum; PR. A. ebenoides; RM. A. pinnatifidim; PM. A. bradleyi (frond on left, Frederick Co., Va., Gilbert 250; frond on right, Madison Co., Mo., Russell); RMM. A. trudellii; RMPM. A. gravesii; PRM. A. kentuckicnse. 
TABLE I

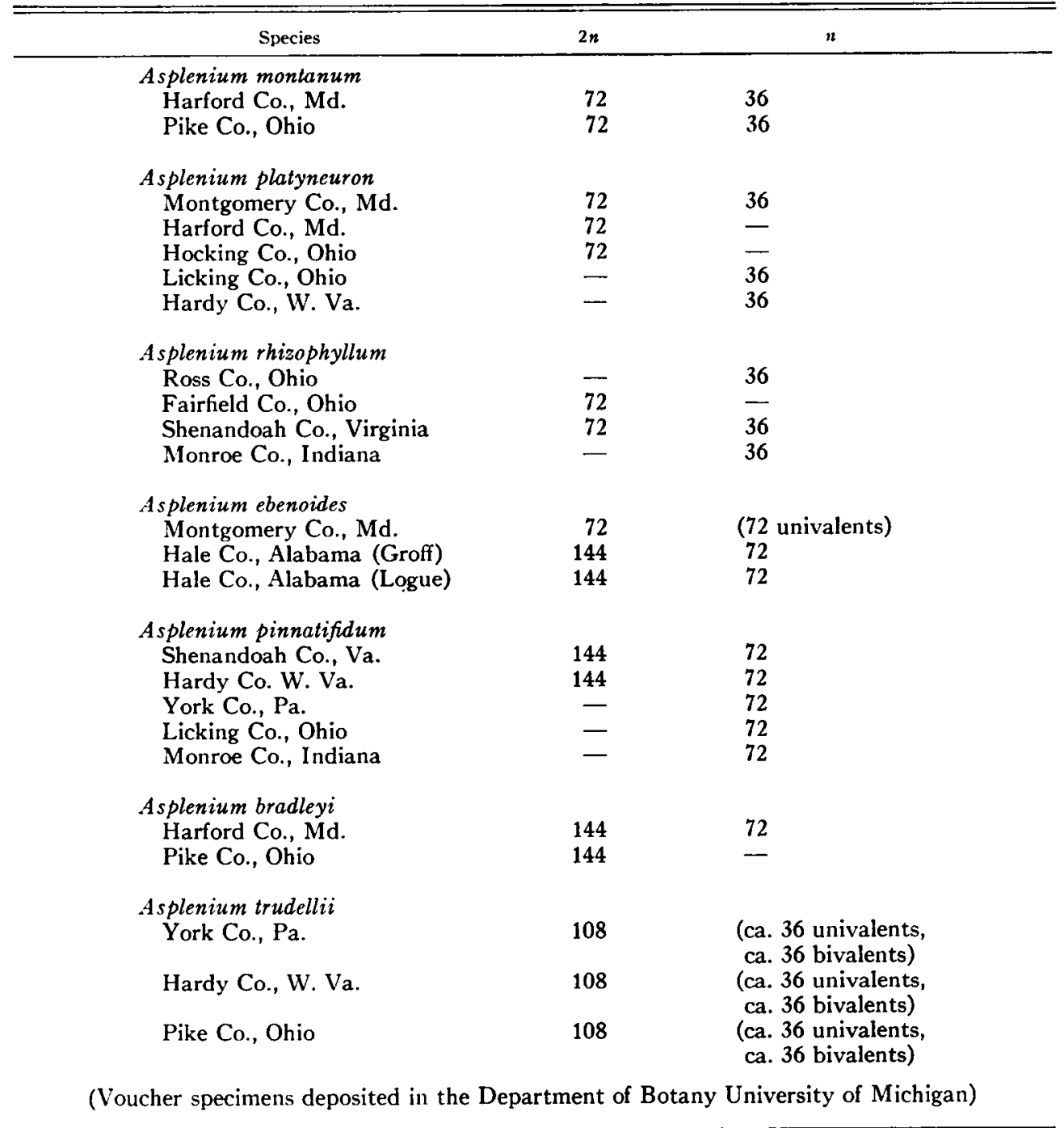

and Hawaii, a species which also possesses the "glossy" upper epidermal cells. $A$. montanum is confined to the eastern United States, occurring from northern Georgia and Tennessee in the Appalachian Region to western Massachusetts. $A$. platyneuron (fig. 1, P), the second of the basic species, has the following distinctions: (1) linear- to oblanceolate-elliptic, once-pinnate, short-petiolate leaf blades, (2) leaf axis entirely dark-brown, including the rounded midrib, (3) upper epi- dermal cells oblong, undulate-walled, and (4) occurrence on rocks and soils of a variety of $\mathrm{pH}$ reactions. It appears to be most closely related to $A$. trichomanes and $A$. resiliens, and its hybrids with the former have been twice recorded ( $A$. virginicum Maxon). A. platyneuron has a very wide range, extending from Texas and Florida in the south to Wisconsin and Kansas to southern Quebec in the north. A. rhizophyllum (Camptosorus rhizophyllus) possesses these character- 
istics: (1) triangular-attenuate, simple leaf-blades, with extremely long, rooting tips, (2) leaf axis green except for the base of the petiole, (3) upper epidermal cells as in $A$. platyneuron, but the venation pattern anastomosing, and (4) occurrence confined almost exclusively to well-shaded, moss-covered tops and sides of rocks and boulders, the $\mathrm{pH}$ reaction of the rock substratum predominantly circumneutral. Its closest relative is $A$. sibiricum of northeastern Asia. A. rhizophyllum, like $A$. platyneuron, is a rather common fern and has a broad range, extending from Alabama and Georgia north to Minnesota and Quebec. The morphological characteristics of these three basic species are intricately blended among the members of the Appalachian Asplenium complex. The chromosome numbers (table 1) of the basic species cannot be used to distinguish them since they all have the same $-2 n=72$, with 36 pairs at meiosis. The number 36 seems to be characteristic of the entire family Aspleniaceae, as was found in European species of Asplenium, Ceterach, and Phyllitis by Manton (1950) and Hawaiian species of Diellia by Wagner (1952).

\section{MEthods}

Observations upon the different described taxa were made in the field and in the herbarium. Some of the entities are, however, exceedingly rare, and field observation of these was impossible, although localities where they had been collected in the past were visited. Dried leaflets were cleared in sodium hydroxide solutions, stained with tannic-acid and iron chloride, and mounted on microscope slides in diaphane in order to examine venation patterns and other anatomical features. Leaf-outline drawings were made on a tracing table, and epidermal-cell drawings with a Bausch and Lomb microprojector. For the cytological study, living plants were grown under greenhouse conditions by $\mathrm{Mr}$. Walter $\mathrm{F}$. Kleinschmidt at the University of Michigan Botanical Gardens. Somatic chromosome counts were obtained from crosiers and young leaflets placed in saturated aqueous solution of paradichlorobenzene for 3 hours to shrink the chromosomes, then placed in fixative. Meiotic studies were made from young sori, fixed directly. The fixative used was 4 parts chloroform; 3 parts ethyl alcohol; and 1 part glacial acetic acid. The specimens were squashed after 24 hours in the solution, and stained in aceto-orcein.

\section{Asplenium Ebenoides}

The first of the intermediates to be discussed is Asplenium ebenoides. Probably no other fern of the New World has attracted so much attention as this hybrid. Wherever its parents, $A$. platyneuron and $A$. rhizophyllum, grow in close proximity, this intermediate appears with gratifying regularity, but usually as a solitary plant, and with sufficient rarity to make its discovery a challenge to the plant collector. Although its hybrid origin was strongly suspected, the finding of the large and obviously self-reproducing population of this fern at Havana Glen, Hale Co., Alabama, some eighty years ago, cast doubt on its true nature. Nevertheless, the careful experiment of Slosson (1902) produced plants by hybridization of the putative parents which were morphologically like $A$. ebenoides, thus firmly establishing the hypothesis of its hybrid origin. Until the present, however, the cytological behavior of the hybrid remained unknown, and the capacity of the Alabama population to reproduce remained unexplained. Two possible hypotheses-hereditary obligate apogamy, and allopolyploidy - were considered as possible explanations of the fertility of this usually sterile plant. Obligate apogamy, it should be noted, is already known in two species of Asplenium, A. monanthes and $A$. resiliens, both of which, though chiefly subtropical, occur in the eastern United States.

The cytological studies of two living plants of the usual, sterile form of $A$. ebenoides from Montgomery Co., Maryland, reveal that there is complete non- 


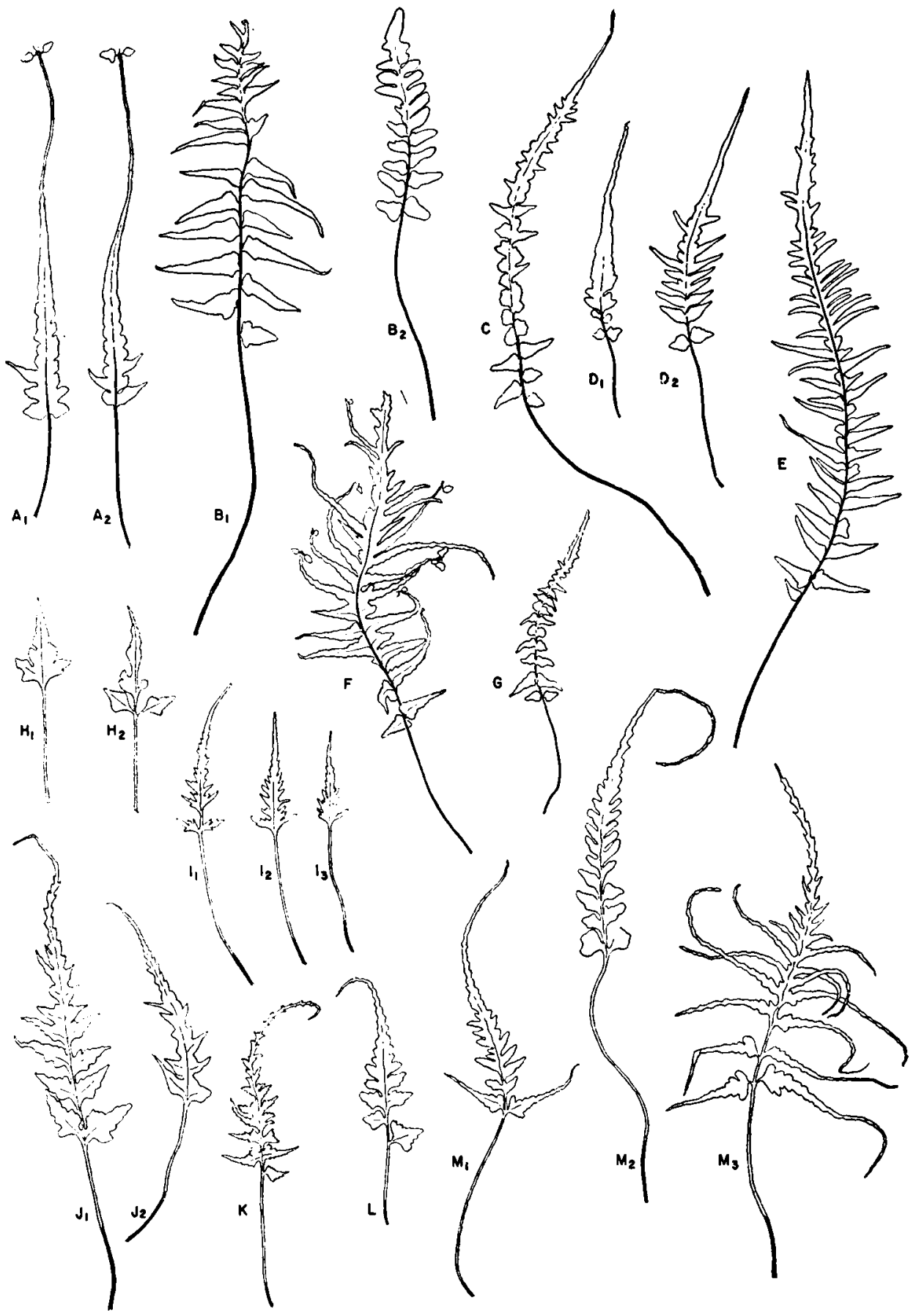

FIG. 2. Leaves showing extreme irregularity. A-G. Asplenium ebenoides (Asplenium rhizophyllum $\times A$. platyneuron) : A. Jefferson Co., W. Va., Wagner \& Rawlings 2016; B. Montgomery Co., Md., Palmer 1899; C. Shenandoah Co., Va., Wagner 241; D. Hale Co., Ala., Maxon \& Pollard; E. Hale Co., Ala. (cultivated, Groff) ; F. Loudoun Co., Va., Gilbert 237; G. Montgomery Co., Md., Wagner. H. Asplenium inexpectatum (A. rhizophyllum $\times$ A. rutamuraria), Adams Co., Ohio, Braun. I-M. Asplenium pinnatifidum ( $A$. rhizophyllum $\times A$. montanum) : I. Patrick Co., Va., Heller; J. Jefferson Co., W. Va., Palmer; K. Jackson Co., Ill., French; L. Madison Co., Mo., Pinkerton; M. Warren Co., Ky., Sadie Price. 
pairing of chromosomes in meiosis. At meiotic metaphase there are visible 72 univalents, 36 from each of the parents (fig. 7, C). By contrast, the investigations of fertile Alabama specimens of this taxon from two collections reveal that the allopolyploid hypothesis explains the situation : dividing somatic cells show 144 chromosomes (fig. 7, $\mathrm{D}_{1}$ ), and during the first meiotic metaphase 72 normal-appearing chromosome pairs are evident (fig. 7, $\mathrm{D}_{2}$ ). The spores produced are normal, but like the stomata, are larger than those of the diploid relatives.

The only certain record of the normal, sexual life cycle in $A$. cbenoides is this occurrence in Hale Co., Alabama. Whether vegetative reproduction explains the multiple plants sometimes found in other localities is not known. A. ebenoides may produce young plants not only at the tips of the leaf blades, but also at the tips of the pinnae; as many as 8 or 10 young plants may be produced on a single luxuriant frond. The large fronds of this plant are usually conspicuously irregular in the lobulation of the blade (fig. 2, A-G), giving them a characteristic bizarre appearance.

It is possible that the origin of the fertile form of $A$. ebenoides by allopolyploidy occurred in recent times and only in one locality, and that this explains why its distribution is so narrow compared to the broader distributions of the two following intermediate types.

\section{Asplenium Bradleyi}

"Bradley's spleenwort" or "cliff spleenwort," though wide-ranging from Okla- homa and Georgia to New Jersey, is rather rare, becoming abundant only locally on steep rock cliffs. However, in recent times the possibility of hybrid origin of this fern has received no attention. As early as 1880 , D. C. Eaton, who described it as a species, wrote the following:

"A. bradleyi varies a good deal in the shape of the fronds and in the degree of incision of the pinnae, the narrower and less divided forms having some resemblance to $A$. platyneuron and the larger forms looking more like $A$. montanum, or the European $A$. lanceolatum. If there could be a hybrid between $A$. platyneuron and $A$. montanum, it would be very much like our plant."

Figure 1, PM, shows two of the different leaf forms of this taxon to illustrate its variability. With present-day knowledge of hybridization in the ferns, and with the evidence now at hand, its describer would not have expressed as much doubt as to its possible hybrid nature. Morphologically it is indeed intermediate between the two parents suggested by him: The rachis of $A$. platyneuron is dark brown, and nearly round in cross-section (fig. $3, \mathrm{P}$ ), with two delicate ridges running along the top side, the ridges separated from each other by a distance of approximately onehalf the diameter of the rachis. In contrast, $A$. montanum has a green rachis which is flattened-triangular in crosssection, the two adaxial ridges appearing as conspicuous, rounded flanges, separated by a wide, shallow groove containing a medial bulge. The midrib of $A$. bradleyi (fig. 3, PM) is intermediate, being brown only in the lower half, and but slightly flattened; the two ridges are separated from each other a distance approximately

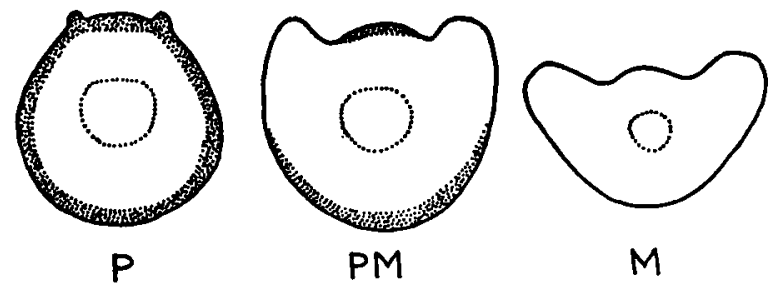

FIG. 3. Diagrams from tracings of midrib cross-sections: P. A. platyneuron; PM. A. bradleyi; M. A. montanum. 


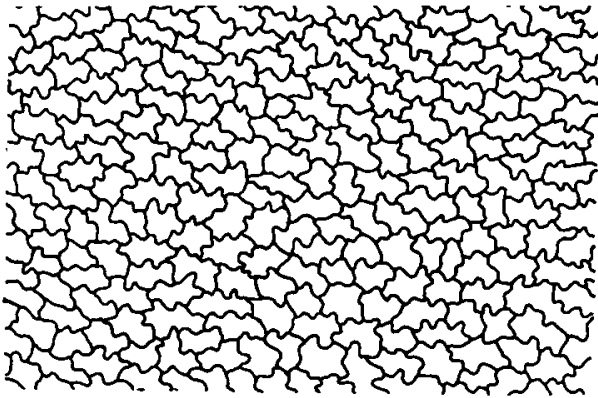

$A_{1}$

(n) ans हn ? $25 \mathrm{~S}^{2}$

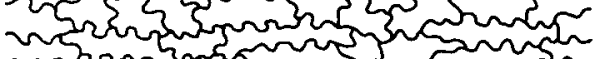
证 ח

$\mathbf{8}^{*}$

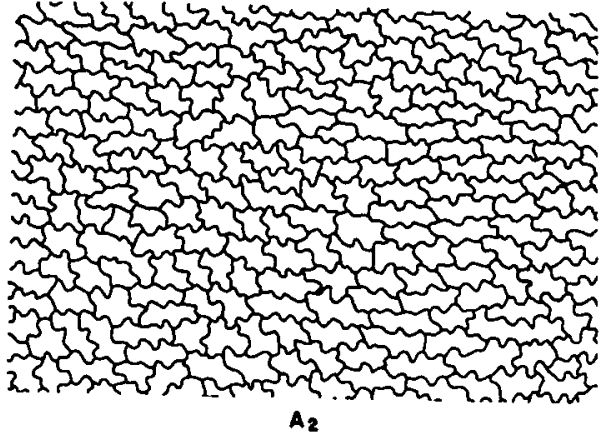

$A_{2}$

$\mathrm{P}_{\mathrm{n}}$ numansons

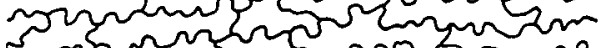

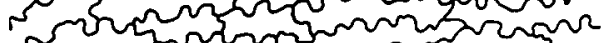

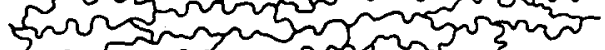
Sunaror 2uran काn ज्ञ r.s?

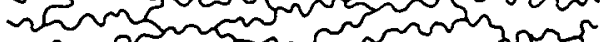

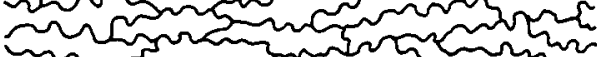
$\mathbf{B}_{2}$
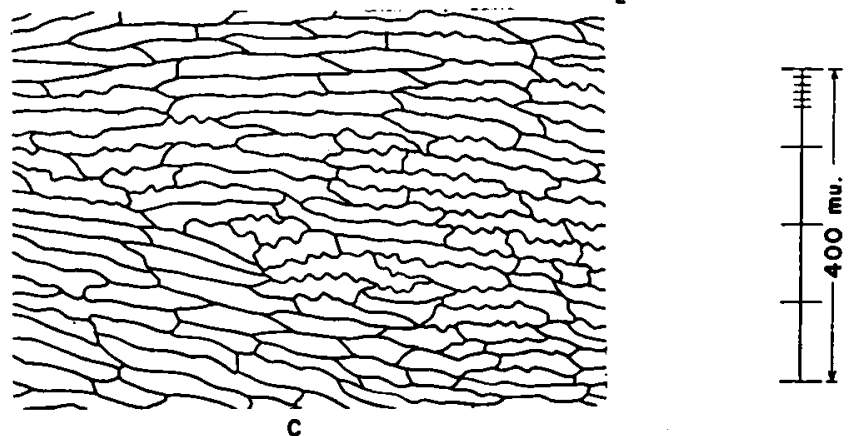

C
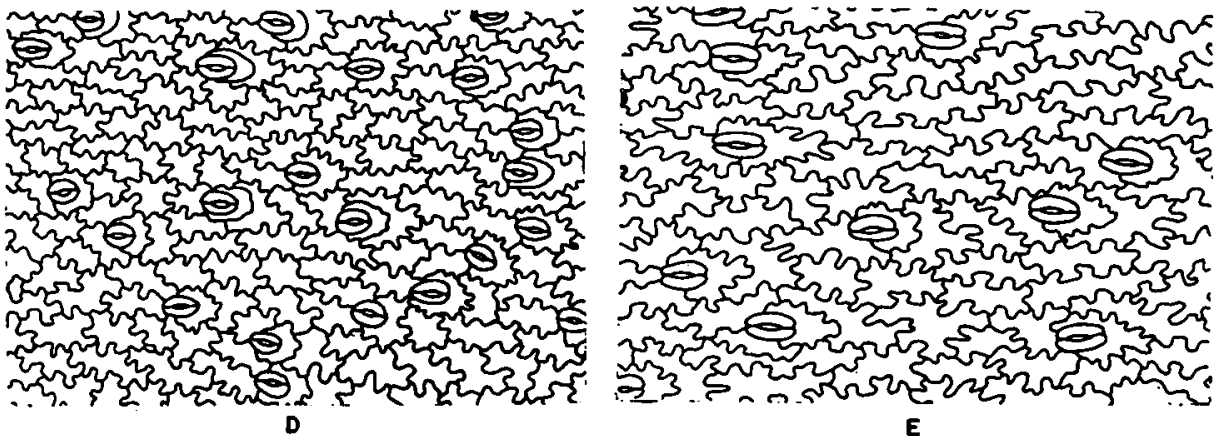

FIG. 4. Epidermal cells. A-C. Upper epidermis: A. Asplenium platyneuron: A, Duval Co., Fla., Churchill; A. Bullock Co., Ga., Harper. B. A. bradleyi: B. Dade Co., Mo., Steyermark 40273; B. Etowah Co., Alabama, Eggert. C. A. montanum, Alleghany Co., N. C., Correll 10817. D, E. Lower epidermis: D. A. platyneuron, Duval Co., Fla., Churchill; E. $A$. bradleyi, Dade Co., Mo., Steyermark 40273. 
equal to the diameter of the rachis, and the upper groove formed between them shows only a slightly elevated, central bulge. Such other $A$. platyneuron features as more or less truncate basal margins of the leaflets and reduced lower pinnae are combined with the elongated tendency of the upper epidermal cells (fig. 4, cf. A, B, and C), the stalked and divided basal pinnae, and the restriction to acid-rock habitats characterizing $A$. montanum. ${ }^{2}$

No individuals of $A$. bradleyi have yet been recorded which are diploid and sterile, although they should be sought for in habitats where the supposed parents occur side-by-side in appropriate conditions. The chromosome number of $A$. bradleyi populations which have been studied is in accord with the allopolyploid hypothesis, being 144 , with normal pairing at meiosis (fig. 7, F). Hybrids of $A$. bradleyi have been recorded with both $A$. platyneuron and $A$. montanum. Probably $A$. bradleyi originated by allopolyploidy in the past at least once, and perhaps several times, but it now has a rather broad range, extending in particular well to the west of the westernmost known limit of one of its putative parents, $A$. montanum.

\section{ASPLENIUM PINNATIFIDUM}

This intermediate is a familiar but rather uncommon fern which occurs from Alabama and Georgia northward to New Jersey, Indiana, and Oklahoma. Its resemblance to $A$. ebenoides is sufficiently close so that the two species are frequently confused. Eaton wrote (1879) that it "bears considerable resemblance to $A$. ebenoides but has a green, herbaceous midrib or rachis, a sinuous-margined prolongation, thicker texture, and is very rarely, if indeed ever, proliferous." Like $A$. ebenoides, $A$. pinnatifidum frequently attracts attention by the irregular appearance of its leaf-forms (e.g., Copeland

\footnotetext{
2 Reports of $A$. bradleyi on "limestone" have proved to be erroneous. Cf. Wherry, Amer. Fern Jour., 21 : 111, 1931.
}

1902), to be discussed below. The larger fronds in any population may be expected to have elongated pinnae at the base of the blade (forma elongatum Morton). $A$. pinnatifidum also resembles $A$. ebenoides in combining the peculiar features of $A$. rhizophyllum with those of the more typical Aspleniums. Concerning the genus Camptosorus as conventionally recognized and typified by $A$. rhizophyllum, Copeland (1947, p. 170) wrote: "Camptosorus is evidently derived from Asplenium. $A$. pinnatifidum Nutt. presents a more definite place of origin in the parent genus." Thus Copeland considers $A$. pinnatifidum (which has also been treated as Camptosorus pinnatifidus Wood) as an Asplenium prototype of Camptosorus. Perhaps the most suggestive resemblance of the two taxa is the attenuated, simple tip of the leaf which, though usually shorter in $A$. pinnatifidum is much like that of $A$. rhizophyllum. However, production of young plants on the leaf tip in $A$. pinnatifidum is decidedly rare and I have found only a few examples. The other major distinction of $A$. rhizophyllum from more typical Aspleniums, that of anastomosing veins, is much more common than budproduction in $A$. pinnatifidum, but the vein areoles form casually and infrequently.

The likelihood is far greater that the $A$. rhizophyllum-like features of $A$. pinnatifidum, rather than indicating community of origin, arose abruptly through hybridization of $A$. montanum with $A$. rhizophyllum. The first suggestion in the literature of this possibility seems to be that by the writer (1950). The chromosome numbers of the five populations thus far investigated accord with this hypothesis, having the $4 n$ number, and four additional populations examined showed the corresponding large-sized stomata. Not only does $A$. pinnatifidum show tendencies toward the features of anastomosing veins, attenuate leaf-tip, and leaf-tip reproduction of $A$. rhizophyllum, but its lamina is thick-textured as in $A$. montanum; moreover there is a definite tend- 
ency toward elongation of the upper epidermal cells, and the basal pinnae or lobes, though simple, have the same outline as in $A$. montanum. The habitat of $A$. pinnatifidum is usually mediacid or subacid soil on rock cliffs as in $A$. montanum, although Craw (1932) found 3 occurrences in Indiana to have neutral soil-reaction, and the writer has seen it in close association with Pellaea glabella, a predominantly calcareous soil plant, at Black Hand, Ohio. $^{3}$

One distinctive feature of $A$. pinnatifidum which points especially strongly to its hybrid origin is the irregularity of the blade outline, seen primarily in larger leaves. The two other hybrids between A. rhizophyllum and more typical Aspleniums ( $A$. platyneuron, fig. 2, A-G; $A$. ruta-muraria, discovered by Braun, 1939, fig. 2, H) likewise display this condition. Rather than a symmetrical system of pinnae or lobes as is characteristic of most ferns, the blades of these hybrids show conspicuous irregularities in pattern, short lobes next to long ones on the same side of the blade, and different patterns of lobulation on opposite sides. ${ }^{*}$

\section{ASPLENiUM TRUDELLII}

Oddly enough, the widespread plant known as $A$. trudellii, which has been interpreted both as a variant of $A$. pinnatifidum and as its hybrid with $A$. montanum, lacks the peculiarity of irregular leafblades, a feature which is sometimes helpful in distinguishing it from $A$. pinnatifidum. A. trudellii has been investigated cytologically from three localities, respec-

${ }^{3}$ Dr. E. T. Wherry has since informed me that the same species-association occurs at Cumberland Falls, Kentucky.

4 The phenomenon of irregularity of leaves of putative hybrids between ferns with widely different leaves is not confined to the Aspleniaceae; it appears, for example, in the Aspidiaceae, Pleuroderris michleriana (Tectaria incisa $\times$ Dictyoxiphium panamense), and in the Pteridaceae, Pteris heteromorpha $(P$. cretica $\times P$. vittata) and $P$. cadieri ( $P$. cretica $\times P$. quadriaurita). tively in Pennsylvania, West Virginia, and Ohio, and the findings not only bear on its own interpretation but on that of A. pinnatifidum as well. Although its describer considered it "possibly in part the result of hybridization between $A$. pinnatifidum and $A$. montanum" (Wherry, 1925), its most recent treatment (Morton, in Gleason, 1952) is as a variety of $A$. pinnatifidum. In 1932, however, Dr. Paul Kestner of Lausanne, Switzerland, found that spores of all specimens of $A$. trudellii he received from Georgia and Tennessee were sterile. In spite of the sterility of its spores-which may also be recognized under the microscope by their irregularity and abortionthis plant, remarkably, is often relatively common where it occurs. But apparently it is never found in the absence of the two presumed parents, $A$. pinnatifidum and $A$. montanum.

Present cytological evidence makes it probable that $A$. trudellii is a hybrid, but its morphology, though intermediate, usually seems somewhat closer to $A$. pinnatifidum than to A. montanum. The chromosome number in all the plants from the three populations studied is 108 , i.e., $3 n$. Also at meiosis there are approximately 36 pairs and 36 univalents, as would be expected in a backcross of an allopolyploid hybrid of $A$. montanum and $A$. rhizophyllum with one of its parents. In 18 wellspread sporocytes the total units of any kind estimated averaged 73.2 (70-75), with 36.3 bivalents $(33-42)$ and 36.9 univalents (33-39). The genetic constitution of $A$. trudellii may thus be now considered to be two genomes of $A$. montanum and one genome of $A$. rhizophyllum.

In spite of its production in considerable numbers, it is dubious whether $A$. trudellii will ever become a reproductive species like $A$. pinnatifidum, because its triploid chromosome complement makes this unlikely. $A$. pinnatifidum, on the other hand, is reproductively a normal species in its present-day behavior, with a typical, sexual life cycle. Its rather 


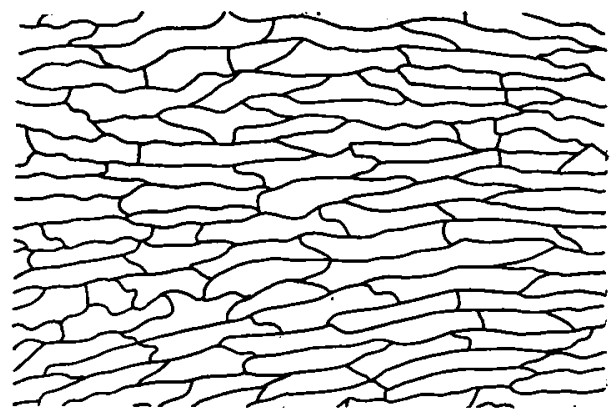

A

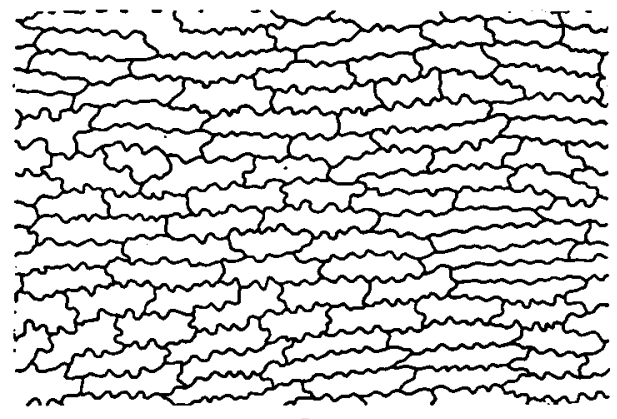

\section{$\theta_{1}$}

innsing \%

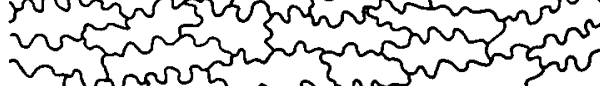

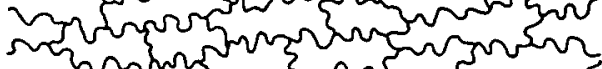

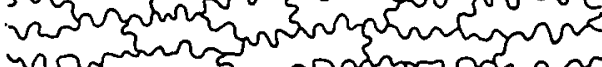
Wr (1) ) (

\section{$\mathbf{C}_{\mathbf{1}}$}

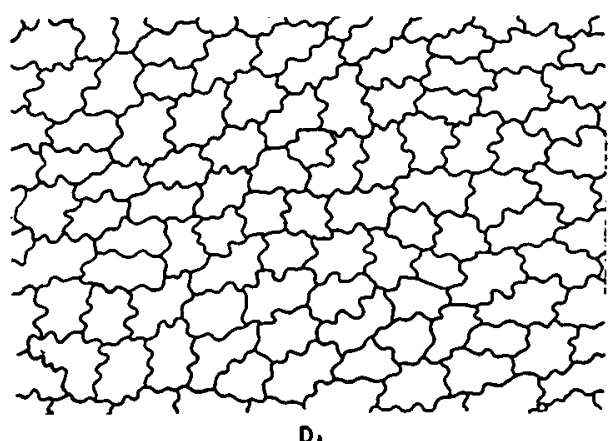

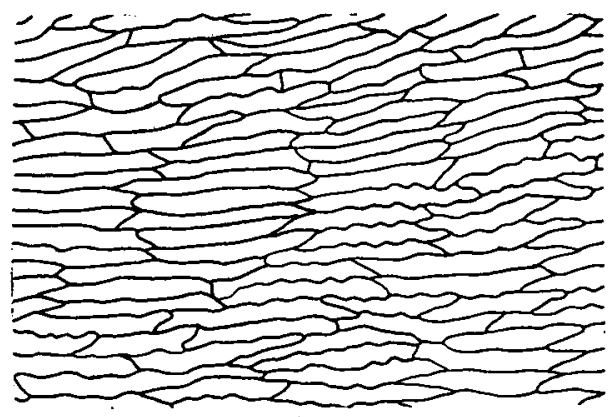

$\mathbf{A}_{2}$

sns

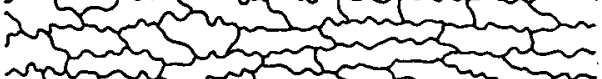
(n)

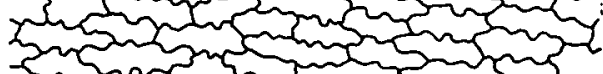
23

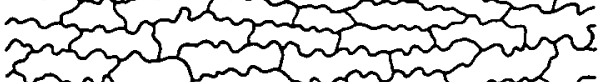
(n) (n) $\mathbf{B}_{\mathbf{2}}$

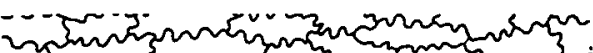

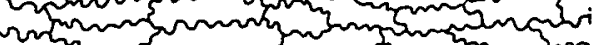
(n)

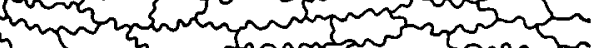
Smanch $2{ }_{3}$ Hon sins

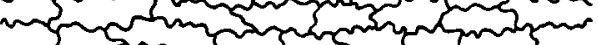

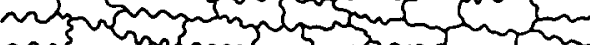
m C.

$$
\mathrm{C}_{\mathbf{2}}
$$

(n)

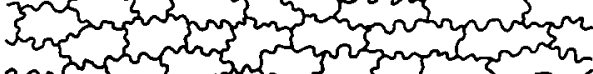
2n (n) ? (2) m (1) का

D2

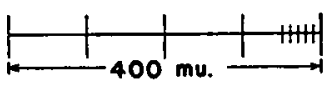

FIG. 5. Upper epidermal cells. A. A. montanum: $\mathrm{A}_{1}$. Macon Co., N. C., Correll 6679; $\mathrm{A}_{2}$ Sevier Co., Tenn., Tryon 33. B. A. trudellii: $\mathrm{B}_{1}$ Etowah Co., Alabama, Eggert; $\mathrm{B}_{2}$. Kentucky, Rule. C. A. pinnatifidum: C1. Carter Co., Mo., Steyermark 11875; C. Union Co., Ill., Hubricht B2287. D. A. rhizophyllum: D, Smith Co., Va., Small; $\mathrm{D}_{2}$. Shenandoah Co., Va., Artz 900. 
wide range suggests ancient origin at least once by doubling of chromosomes in an original hybrid. Plant collectors should certainly seek in the field individuals of A. pinnatifidum which are diploid and sterile, to be expected where $A$. rhizophyllum and $A$. montanum occur in close proximity.

\section{ASPLENIUM KentUCKIENSE AND}

\section{A. GRAVESII}

Asplenium kentuckiense, discovered and described first by McCoy (1936), represents the theoretical central point morphologically in the entire Appalachian Asplenium complex. Although McCoy did not discuss its hybrid origin, Wherry (1936) first suggested that it represented an intermediate between $A$. pinnatifidum and $A$. platyneuron. (The other plant, $A$. stotleri, mentioned by Wherry in this connection, is now believed to involve an additional species outside the complex.) Besides the morphology of $A$. kentuckiense, which is intermediate between the two supposed parents, additional observations indicate that it is the cross of $A$. platyneuron and $A$. pinnatifidum: (1) three plants were collected by Mr. Floyd Bartley in Hay Hollow, Pike Co., Ohio, in the immediate vicinity of the two putative parents; (2) in southern Illinois, where $A$. kentuckiense was found by Earl (specimen in Chicago Museum), only $A$. platyneuron and $A$. pinnatifidum of possible parents are present, neither $A$. bradleyi nor $A$. montanum being known from that state. Specimens believed to represent $A$. platyneuron $\times A$. pinnatifidum are now known from scattered points in Kentucky, Ohio, Illinois, and Arkansas, and they all possess abortive spores. Although no living plants have been available for study, the stomatal sizes of preserved material indicate the $3 n$ condition.

Stomatal size seems especially useful in the determination of dried material of the rarer ferns in this complex, the material being relaxed in sodium hydroxide solutions, cleared, and treated as described above. The stomata of one pinna or fragment of all these plants under discussion may vary in length as much as 11 to 18 microns, and the averages of different collections of one species as much as 5 to 10 microns. Nevertheless it has ustally proven possible by averaging 30 measurements of stomatal lengths of a pinna from a single collection to distinguish the polyploid levels. The fertile tetraploids have conspicuously large stomata. Individual collections of known or theoretical triploids may have values which overlap some of the diploids and some of the tetraploids, as shown in the chart below of averages of 30 stomatal lengths in $\mathrm{mi}$ crons of each of 31 collections :

\section{Diploids}

(range of averages of 11 collections, 39-45).

A. rhizophyllum ( 3 collections). .41 (40-41)

$A$. ebenoides ( 2 collections) .....40 (39-40)

A. platyneuron ( 3 collections) ...42 (40-43)

A. montanum (3 collections) .....42 (40-45)

Triploids

(range of averages of 9 collections, 42-51). A. bradleyi $\times$ montanum ( 2 collections) $44(42-45)$

A. trudellii (4 collections) .....46 (42-51)

A. kentuckiense ( 3 collections) ..45 (43-48)

Tetraploids

(range of averages of 11 collections, 46-58).

A. gravesii (4 collections) .......49 (46-53)

$A$. ebenoides ( 1 collection) ......54

A. pinnatifidum ( 3 collections) ...55 (50-58) A. bradleyi ( 3 collections)......56 (52-58)

Asplenium gravesii, described by Maxon (1918) as a hybrid of $A$. pinnatifidum and $A$. bradleyi, has been found in a limited number of localities in Georgia, Alabama, Ohio, and Pennsylvania. "Judging $A$. gravesii on both gross and minute characters, there can be little doubt of its hybrid nature, making all allowance for the unusually high variability of the supposed parents, of one or the other of which it might at first be thought an extreme state" (Maxon, loc. cit.). $A$. gravesii may be distinguished from $A$. kentuckiense by having less brown on the leaf-axis, pinna shape, thicker texture of the blade, somewhat more elongate upper 


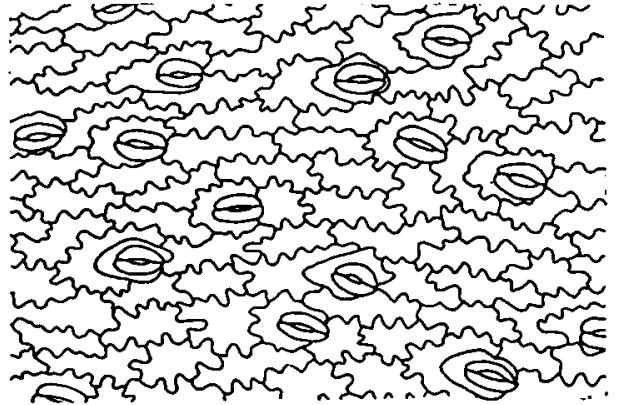

$A_{1}$

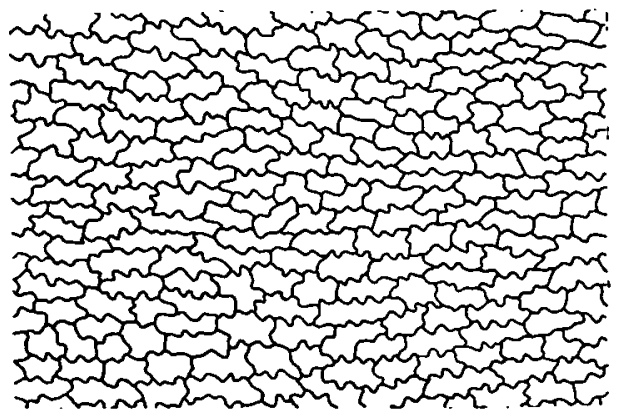

B

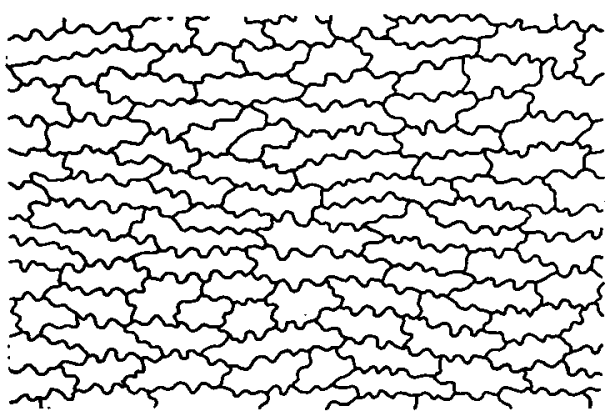

$c_{1}$
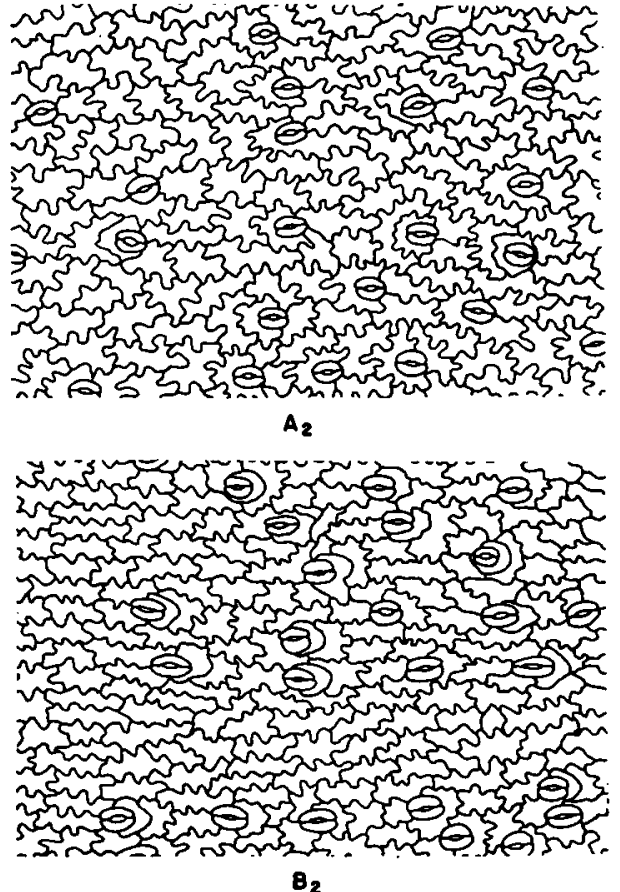

$\mathbf{B}_{2}$

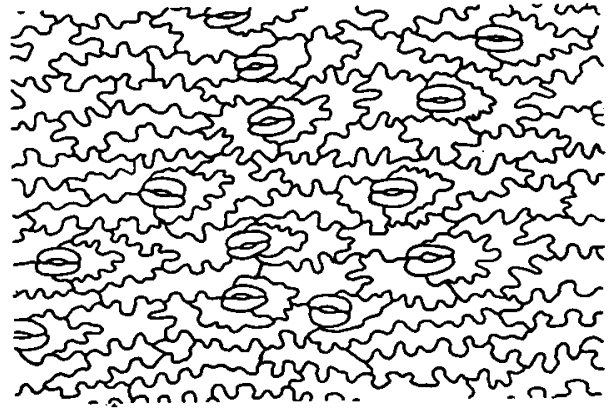

$\mathrm{C}_{2}$

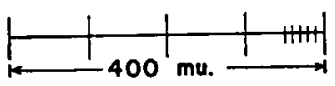

FIG. 6. Epidermal cells: A. Asplenium ebenoides, upper epidermis: A. Hale Co., Alabama, Maxon \& Pollard (4n); A. Montgomery Co., Md., Wagner. B. A. kentuckiense, S. Illinois, Earl: $\mathrm{B}_{1}$. Upper surface; $\mathrm{B}_{2}$. Lower surface. C. A. gravesii, Trenton, Ga., Graves: $\mathrm{C}_{1}$. Upper; $\mathrm{C}_{2}$. Lower surface.

epidermal cells (cf. fig. 6, B and C), and the usually somewhat larger stomatal sizes suggesting the $4 n$ state. However, the two ferns are similar morphologically, and young plants especially may prove to be difficult to identify on gross characteristics. Both are exceedingly rare, and no living material has been seen by the author or is expected in the near future.
These two intermediate ferns, $A$. gravesii and $A$. kentuckiense, combine morphologically distinctions of all three of the basic diploid species, in respect to such features as the extent of brown on the leafaxis, the degree of attenuation of the leaftip, pinna shape, etc. But $A$. kentuckiense possesses unusual theoretical interest in this problem since it presumably repre- 


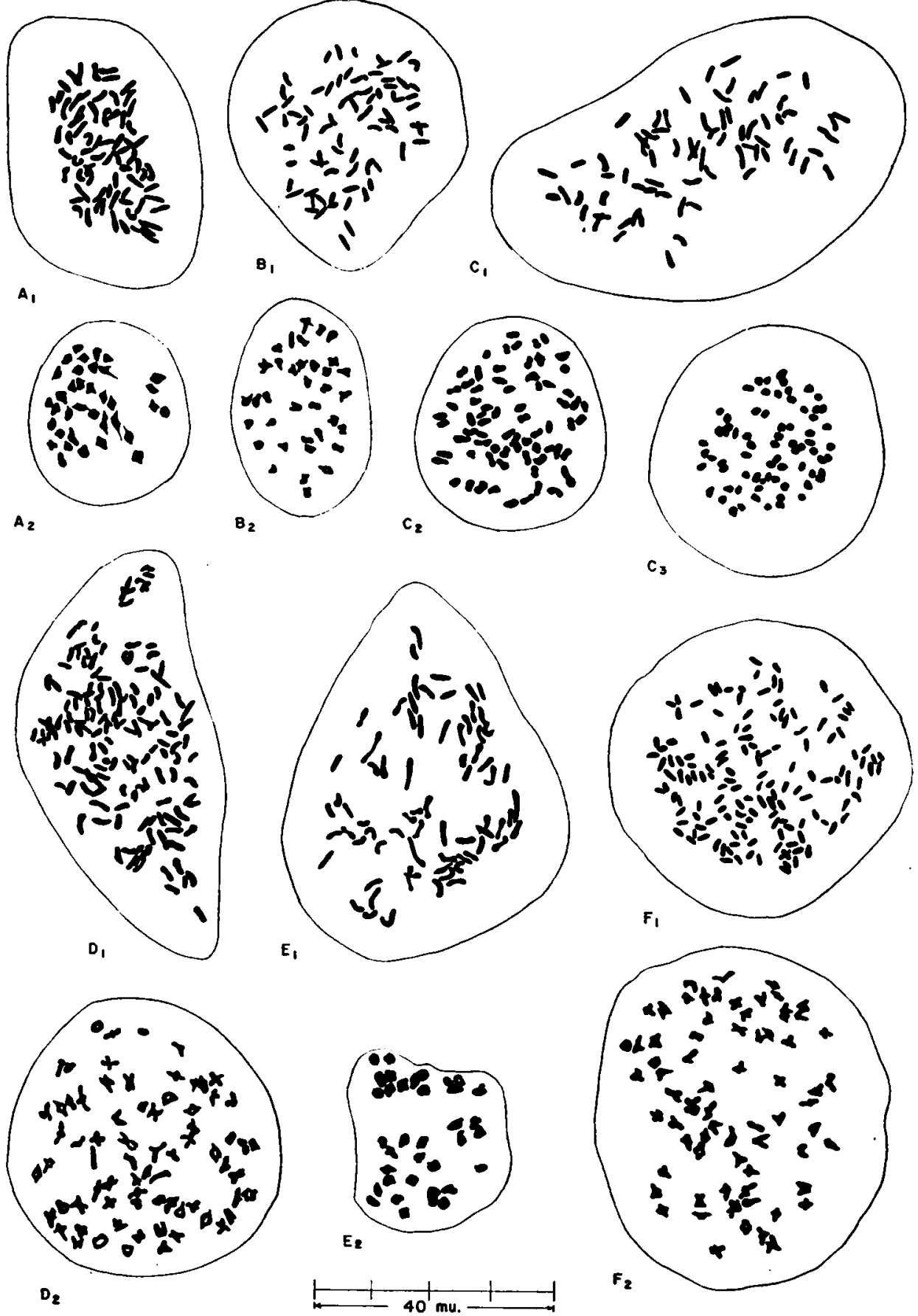

FIG. 7. Chromosomes of Appalachian Aspleniums. A. Asplenium platyneuron: $\mathrm{A}_{\mathrm{r}}$. Montgomery Co., Md., $2 n=72$; $\mathrm{A}_{2}$. Hardy Co., W. Va., 36 pairs. B. Asplenium rhizophyllum: $\mathrm{B}_{1}$. Shenandoah Co., Va., $2 n=72$; Monroe Co., Indiana, 36 pairs. C. Asplenium ebenoides (sterile form), Montgomery Co., Md.: $C_{1} .2 n=72 ; C_{2}$ and $C_{3} .72$ univalents at meiotic metaphase. $D$. Asplenium ebcroides (fertile form), Hale Co., Alabama: $D_{1}, 2 n=144 ; D_{2} .72$ pairs. $\mathrm{E}$. Asplenium montanum, Harford Co., Md.: $\mathrm{E}_{2} .2 n=72 ; \mathrm{E}_{2} .36$ pairs. F. Asplenium bradleyi: $F_{1}$. Pike Co., Ohio, $2 n=144 ; F_{2}$. Harford Co., Md., 72 pairs. 
sents the precise morphological central point between the "poles" of the triangle of basic, diploid species (fig. 1, PRM). Thus it should theoretically be possible to produce triploid $A$. kentuckiense in all of the following experimental crossings:

A. montanum $(2 n) \times A$. ebenoides ( $4 n$ )

A. rhizophyllum $(2 n) \times A$. bradleyi $(4 n)$

$A$. platyneuron $(2 n) \times A$. pinnatifidum (4n)

\section{Discussion}

Stebbins (1950) has discussed the role of polyploidy in plant evolution, and cites a number of established or suspected allopolyploids among flowering-plants, including Galeopsis tetrahit (G. pubescensspeciosa) and Iris versicolor (I. setosa- virginica) and others which occur as normal species. Only recently, however, has allopolyploidy in species of the Filicineae been subjected to investigation: Manton (1950) has shown that seven European ferns with normal life-cycles, including Dryopteris filix-mas and Polystichum aculeatum, are either suspected or demonstrated allopolyploids. More recently (Manton and Walker, 1953) it has been shown that the American Dryopteris clintoniana is a hexaploid and "is perhaps the amphidiploid hybrid between normal $D$. cristata [a tetraploid species] and $D$. goldiana [a diploid]."

Perhaps the most interesting aspect of the Appalachian Asplenium complex is that the polyploid taxa combine features

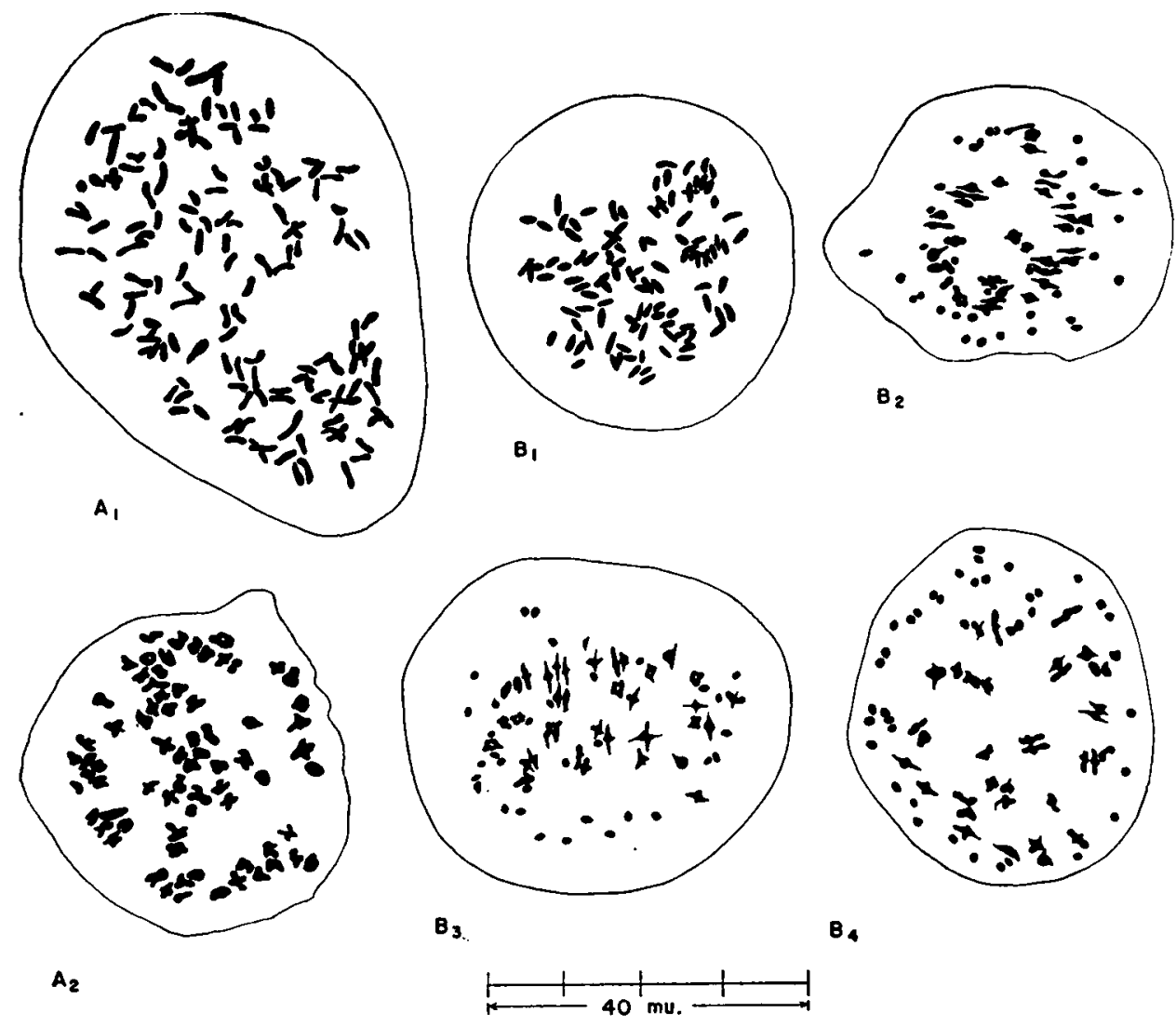

FIG. 8. Chromosomes of Appalachian Aspleniums. A. Asplenium pinnatifidum: $\mathrm{A}_{1}$. Shenandoah Co., Va., $2 n=144$; $\mathrm{A}_{2}$. Monroe Co., Indiana, 72 pairs. B. A. trudellii: $\mathrm{B}_{1}$. York Co., Pa., $2 n=108 ; \mathrm{B}_{2}$. York Co., Pa., approximately 36 pairs and 36 univalents at meiotic metaphase; $B_{3}, B_{4}$. Hardy Co., W. Va., approximately 36 pairs and 36 univalents. 
of diploids of widely different morphology and relationship. The suspected allopolyploid, "Scolopendrium hybridum," of Europe (Manton, 1950) likewise combines features of very unlike putative parents, Asplenium (Scolopendrium) hemionitis and $A$. (Ceterach) ceterach. The polyploids of the Appalachian Asplenium complex appear to be "typical or genomic allopolyploids" (Stebbins, op. cit., p. 226) resulting from hybridization of distantly related species in which the chromosomes are so different that normal pairing would be impossible in the diploid. The polyploid intermediates between the presumably basic diploid species in this complex are clear-cut intermediates, and there is evidently no tendency toward introgression between parent species since gene interchange through the diploid hybrids is extremely unlikely.

Two of the diploid species of this complex, Asplenium rhizophyllum and $A$. platyneuron, are much more abundant than their apparent allopolyploid derivatives, in contrast to many of the previously reported allopolyploids among plant species. One of the allopolyploids discussed here, namely $A$.ebenoides, is very limited in range, while the two others, $A$. bradleyi and $A$. pinnatifidum-although generally less common than $A$. montanum where their ranges overlap with it-have extended their ranges farther westward than this presumably parental, diploid species, but not farther northward.

Of the theoretically possible sterile hybrids in this complex, five still remain to be discovered, but their arising under natural field conditions seems extremely unlikely because of parental differences in ranges and habitat preferences. Even what is perhaps the most expected of the still unknown hybrids, $A$. rhizophyllum $\times$ $A$. pinnatifidum, may never be found under natural conditions because these species so rarely occur close together. Of the four theoretically possible fertile polyploid hybrids, only one-hexaploid $A$. kentuckiense-has not yet been found in the natural state, although the possibility of the origin of such a form should be recognized by field-workers.

\section{Conclusions}

The Appalachian Aspleniums comprise 11 described taxa, of which 3 represent morphological extremes and the remainder intermediates. $A$. ebenoides is a usually sterile hybrid of $A$. platyneuron and $A$. rhizophyllum with 72 univalents at meiotic metaphase, although one population from Alabama is a fertile allopolyploid, forming 72 normal bivalents at meiosis. $A$. bradleyi is apparently the allopolyploid hybrid of $A$. montanum and $A$. platyneuron; it back-crosses with both parents. $A$. pinnatifidum likewise is evidently an allopolyploid hybrid, and its morphology, the irregularity of the leaves, and the pairing behavior of its putative backcross ( $A$. trudellii) with one of the parents indicates that its parentage is $A$. montanum $\times A$. rhizophyllum. $A$. kentuckiense and $A$. gravesii are both evidently trihybrids, the former $3 n$, the latter $4 n$, and $A$. kentuckiense morphologically represents the theoretical central point of the whole complex. A hypothesis of reticulate evolution is thus presented for the Appalachian Aspleniums which postulates that three original diploid species, $A$. montanum, $A$. platyneuron, and $A$. rhizophyllum, have given rise to 8 additional taxa through hybridization.

\section{ACKNOWLEDGMENTS}

I am indebted to Dr. G. Ledyard Stebbins and to Dr. Edgar T. Wherry for critical reading of the manuscript, and to Mr. Walter F. Kleinschmidt for growing the living plants. I wish also to thank those persons who so kindly supplied living materials for study, including $\mathrm{Mr}$. Floyd Bartley, Mr. Donald F. M. Brown, Mr. Neal W. Gilbert, Miss Mary E. Groff, Dr. Charles B. Heiser, Dr. Everett G. Logue, Dr. Erich Steiner, Mr. Harry Trudell, and Dr. Wherry, and those herbaria which sent dried materials, including the University of Pennsylvania, 
U. S. National Museum, Chicago Museum, University of Illinois, and Missouri Botanical Garden. Mr. Hubert M. Vogelman helped me with the drawings.

\section{Literature Cited}

Alston, A. H. G. 1940. Notes on the supposed hybrids in the genus Asplenium found in Britain. Linn. Soc. London Proc., Session 152, 1939-40 (Part 2) : 132-144.

Braun, E. Lucy. 1939. A new fern hybridAsplenium cryptolepsis $\times$ Camptosorus rhizophyllus. Amer. Fern Journ., 29: 133-135.

Copeland, E. B. 1902. Two fern monstrosities. Bot. Gazette, 34 : 143-144.

- 1947. Genera Filicum. Waltham, Mass.

Craw, JoE E. 1932. Hydrogen-ion reaction of native Indiana fern soils. Butler Univ. Bot. Studies, 2: 151-158.

EATON, D. C. 1879-80. Ferns of the United States. I and II. Salem, Mass.

Gleason, H. A. 1952. The new Britton and Brown Illustrated Flora of the northeastern United States and adjacent Canada. Vol. I. Lancaster, $\mathbf{P a}$.

Manton, I. 1950. Problems of cytology and evolution in the Pteridophyta. Cambridge.
Manton, I., and S. Walker. 1953. Cytology of the Dryopteris spinulosa complex in Eastern North America. Nature, 171: 11161118.

Maxon, William R. 1918. A new hybrid Asplenium. Amer. Fern Journ., 8: 1-3.

McCoy, Thomas N. 1936. A new Asplenium from Kentucky. Amer. Fern - Journ., 26: 104-106.

Slosson, Margaret. 1902. The origin of Asplenium ebenoides. Torrey Bot. Club Bull., 29 : 487-495.

StebBins, G. L., JR. 1950. Variation and evolution in plants. New York.

WAGNER, W. H., JR. 1950. Cytotaxonomic analysis of evolution in Pteridophyta (review). Evolution, 5: 177-181.

- 1952. The fern genus Diellia. Univ. Calif. Publ. Bot., 26: (no. 1) : 1-212.

- 1953. A cytological study of the Appalachian spleenworts. Amer. Fern Journ., 43: $109-114$.

WhERRY, E. T. 1925. The Appalachian Aspleniums. Amer. Fern Journ., 15: 47-54.

- 1927. Notes on Asplenium trudellii. Amer. Fern Journ., 17 : 135-138.

Wherry, E. T., and William D. Gray. 1936. Variants of some Appalachian Aspleniums. Amer. Fern Journ., 26: 77-86. 